regulated to correspond with between 0.7 and 0.9 per cent. of sodium chloride.

It is strange that the mechanism governing this vital regulation should not have been grasped before. The cells and circulating medium are saturated with colloids, and this amount of $0.7-0.9$ per cent. of saline is just the amount the colloids are capable of holding in crystallo-coiloidal adsorption. Any more is at once filtered away; any less, and life ceases.

There are many other applications in biology and medicine, but they cannot be treated within the compass of a letter.

I4 Frognal, Hampstead.

\section{The Audibility of Thunder.}

IT has been stated that thunder is not usually heard at a greater distance than about twelve miles. This may be so during the day, but at night it can frequently be heard at a much greater distance from its point of origin. Some years ago I timed an interval between flash and sound over the sea, and found it to be more than tivo minutes. During the storm of September 5 last my. son, Lieut. F. O. Cave, and I timed an interval by a method of counting seconds often adopted by photographers, with which method we were both familiar; one of us made it I40 seconds, the other I4I seconds. The flash was a particularly bright one; we had previously heard fainter thunder corresponding with less bright flashes, which were presumably a good deal further away.

On the night of October $\mathrm{I}-2$ a thunderstorm passed up-Channel to the south of this locality; any rainfall must have been beyond the $\mathrm{Nab}$ and the Warner lightships, as both lights were plainly visible: their distances are $I 7 \frac{1}{4}$ and $I 6 \frac{3}{2}$ miles respectively if they are in their pre-war positions. With the help of an electric clock, which moves on every half-minute, supplemented by counting seconds, I made one timeinterval I20 seconds and another '170 seconds; then with a stop-watch I timed an interval of $I 89$ seconds.

During the storm of October $\mathrm{I}-2$ the pheasants crowed much more loudly than usual, especially at the early rumbles of thunder, or else the audibility was exceptionally good; probably the latter was the case, as the night was very clear and the air in the valley' from which the crowing came would have been colder than the air here, a condition which would probably be favourable for good audibility of sounds coming from the valley, though it would scarcely account for the audibility of the much more distant thunder. It mav be worth noting that the false cirrus above the thunder-cloud was lit up by light reflected from the aurora which was extremely brilliant at the time.

Ditcham Park, Petersfield, October 6. C. J. P. CAve.

\section{OPEN-AIR NATURAL HISTORY.1}

(I) $M$ R. LOVELL'S book is the outcome of welcome to botanists, entomologists, and beekeepers. It deals with the inter-relations of flowers and insects, especially as regards pollination; it "treats of plants alive and in the midst of their home surroundings"; it justifies the

1 (r) "The Flower and the Bee: Plant Life and Pollination." By John H. Lovell. Pp. xvii+286. (London: Constable and Co., Ltd., rgrg.) Price ros. $6 \pi$. net

(2) "Insect Artizans and Their Work" By Edward Step. (Hutchinson's Nature Library.) Pp. $x+318$. (London: Hutchinson and Co., n.d.) Price 75. 6 d. riet.

(3) "The Seashore: Its Inhabitants and How to Know Them." By F Robson. Pp. rrr. (London: Holden and Hardingham, Ltd., n.d.) Price is. $6 d$. net.

$$
\text { NO. } 2607 \text {, VOL. IO4] }
$$

author's prefatory remark that "the identification of a species should be regarded merely as an introduction and the beginning of a friendship long to be continued." The book is written with enthusiasm and popularly, but it is a scientific record of personal observations of great interest, and it includes some notes on modern theories which should be carefully considered. It is illustrated with conspicuously successful photographs, which have been taken on panchromatic plates to preserve in monochrome the proper colour values.

Beginning with a short historical sketch, in which tribute is paid to Sprengel, Hermann Müller, and Darwin, the author discusses wind-pollinated flowers, the rôle of hive-bees especially in relation to blue flowers, the humble-bee's favourite flowers which are mostly irregular in shape, the short-cuts taken to the nectaries, the crabspiders which lurk in flowers and pounce on the insect-visitors, the "oligotropic" bees that rarely visit more than one kind of flower, the predominantly reddish butterfly-flowers like pinks and some Compositæ, the work of nocturnal moths in relation to flowers like evening primrose and honeysuckle, the fly-flowers like Linnaea borealis which is visited by the dance-fly (Empis rufescens), and those with nauseous odours like the carrion-flower and the skunk-cabbage, the usually injurious visits of beetles, flowers like wild roses, mulleins; and poppies which are visited for pollen, not nectar.

Mr. Lovell discusses the experimental evidence of the value of having conspicuous flowers and of colour-discrimination on the part of bees. In regard to the latter, however, the discussion is inadequate, for no experiments are conclusive that do not distinguish between colour as such and differences in intensity of illumination. A very interesting general chapter deals with the colours of flowers. Of the 4020 flowering plants in northeastern America, the greens, whites, and yellows number $300 x$, while the reds, purples, and blues amount to only rorg. The latter are, on the whole, of more recent origin, and have evolved from the others, the selective agency of insects playing its part. In conclusion, the author discusses the value of bees in connection with fruitgrowing, and notably in securing cross-fertilisation, the importance of which is very strongly emphasised.

The author has written a fine book on a fine subject, and his treatment should stimulate further study. We wish that he had been able to devote a special chapter to theoretical considerations, for, though he believes in the transmission of acquired characters, in the efficacy of insects as selective agents, in orthogenesis carrying plants beyond the limits of the advantageous, and in the evolutionary importance of crossing, he says tantalisingly little on these subjects. From an observer of Mr. Lovell's experience we should like to hear more.

(2) Mr. Step has written a delightful book on the industries of insects, which he arranges under headings corresponding with human occupations. $\mathrm{He}$ directs attention to the interesting fact that 
many of the activities are very specific and very intricate, yet there can be no help from parental instruction. "In the vast majority of species the parent is dead long before the daughter comes to that stage of existence when the necessity for making provision for her progeny arises, so the knowledge has to pass by way of transmitted memory. Somewhere in the minute speck of protoplasm constituting the egg of one of the solitary bees there is an infinitesimal particle of nerve (two of which are here reproduced) deserve high praise, both the photographs by the author and the drawings by Mr. Carreras.

(3) Mr. Robson's little book attempts the impossible, and does not succeed. The space is, indeed, inadequate for an interesting account of the inhabitants of the seashore, but it might have been used more skilfully; the illustrations are not very happy; there are several inaccuracies in the brief text; and there are far too many mis-

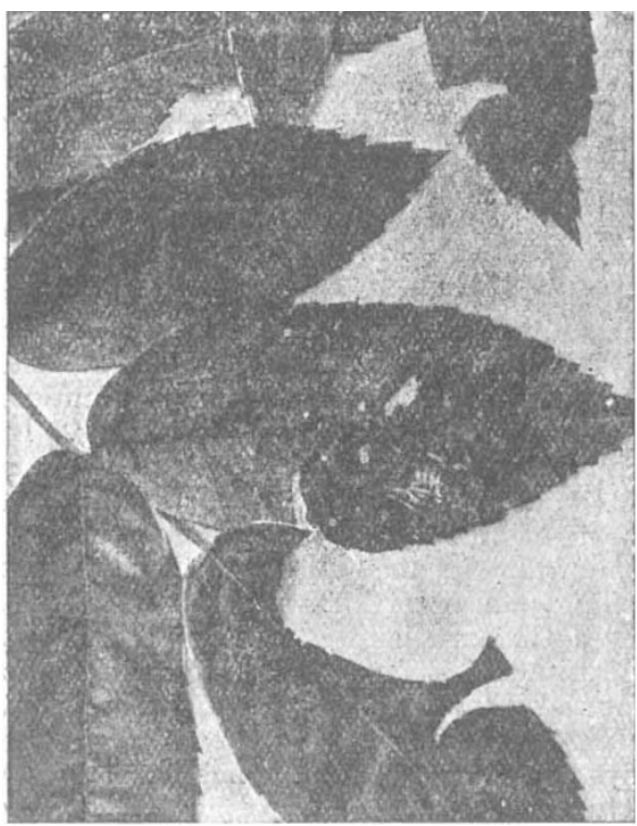

FIG. 1.-Leaf-cutter Bee.

The left photo shows the bee at work. The right photo is a section of an old post and shows the thimble-shaped cells made from the cut portions of leaves. From "Insect Artizans and their Work."

matter which contains the secret of how to cut accurate circles and ovals of rose-leaf so that a number of them will overlap and curve into a. perfect cylinder. During the greater part of its life the creature that hatches out from that egg will have no need of the secret, but the germ of it will go on developing, and when the insect has attained to the complete bee form there is the idea in the memory cells ready to instruct the nerves that govern the action of wings and legs and cutting jaws." We have quoted this at length, for it expresses Mr. Step's view of the big riddle that lies behind his book. Unfortunately, we do not know how the secret is kept in the egg before there is any particle of nerve matter, or how the insects get the knowledge which forms the contents of the transmitted memory, or whether they really have an idea which instructs the nerves. But the author usually chooses the wise path of keeping to the facts, and gives us a charming account of spinners and weavers, miners and masons, carpenters and wood-workers, upholsterers, wax-workers, papermakers, tailors, horticulturists, sanitary officers, musicians, burglars, and lamp-bearers. The book is fresh and competent, and the illustrations NO. 2607, VOL. IO4]

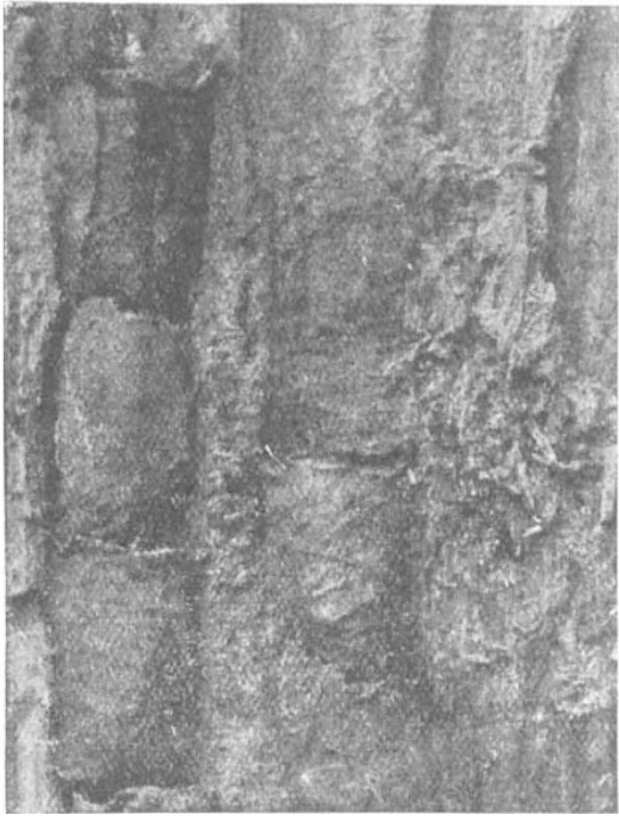

prints. Several excellent inexpensive guides to the seashore, as much within children's compass as this book is, are readily available.

\section{THE RECONSTRUCTION OF THE FISHING INDUSTRY.}

I N November of last year the National Sea Fisheries Protection Association made proposals for a unification of fishery administration, and it embodied these in a "Memorandum" (which was referred to in NATURE of November 28 , I9I8, p. 248). The memorandum was submitted to $\mathrm{Mr}$. Prothero, who doubtless acquainted the Cabinet with its provisions, but that was all that happened. Eight months afterwards the Government introduced a Bill for the establishment of a Standing Fishery Advisory Committee, and for the removal of the statutory limitation of the salary of the President of the Board of Agriculture and Fisheries!

The I9I8 memorandum recommended the creation of a United Kingdom Ministry of Fisheries, but its authors found that they were "up against" the opposition of the Scottish industry. So when a special joint committee of the association pre- 